\title{
THE IMPACT OF THE EPIDEMIC THREAT ON THE DESIGN OF OFFICE SPACE AND OFFICE BUILDINGS
}

\section{WPŁYW ZAGROŻENIA EPIDEMICZNEGO NA PROJEKTOWANIE BIUR I BUDYNKÓW BIUROWYCH}

\author{
Marcin Goncikowski \\ dr inż. arch. \\ Author's Orcid number:0000-0003-3848-2810 \\ Wydział Architektury Politechniki Warszawskiej \\ Katedra Zakład Projektowania i Teorii Architektury \\ Pracownia Architektury Przemysłowej i Wielkoprzestrzennej
}

\begin{abstract}
The topic of the paper is determining the impact of an epidemic threat situation on the design of office space and office buildings. The types of actions taken to improve safety are: procedural actions, modifications of technical solutions: architectural and installation and remote work. Solutions in the field of office space architecture include: reducing the density of occupants, introducing partitions, eliminating multi-person offices, using materials that are easy to disinfect and clean, opening windows and installing personal protective equipment dispensers. The installation solutions include air quality improvement, filtration and disinfection systems as well as telecommunication installation systems supervising the use of the building. It can be expected that in the future, technical solutions will be introduced into the designs of buildings and office spaces, which will be a place for meetings, spontaneous interactions, mutual inspiration of employees and strengthening their identification with the employer whereas the ratio of office work places will be lower. The structure of the building is likely to change to a richer commertial part, a co-working part and flexible offices, and a traditional part of office space for lease, but as such office buildings will still be needed.
\end{abstract}

Key words: architecture, office space, office buildings, Covid-19.

\section{STRESZCZENIE}

Praca poświęcona jest określeniu wpływu sytuacji zagrożenia epidemicznego na projektowanie przestrzeni biurowej i budynków biurowych. Typy działań podejmowanymi w celu poprawy bezpieczeństwa są działania proceduralne, modyfikacje rozwiązań technicznych: architektonicznych i instalacyjnych oraz praca zdalna. Rozwiązaniami w zakresie architektury przestrzeni biurowej są: zmniejszanie zagęszczenia, wprowadzanie przegród, eliminacja wieloosobowych biurek, stosowanie materiałów łatwych w dezynfekcji, otwieranych okien, instalacja dyspenserów środków ochrony osobistej. Rozwiązaniami instalacyjnymi są systemy poprawy jakości powietrza, jego filtracji i dezynfekcji oraz systemy instalacji teletechnicznych nadzorujących użytkowanie budynku. Można spodziewać się, że w przyszłości rozwiązania techniczne zostaną wprowadzone do projektów bu- 
dynków i przestrzeni biurowych, które będzie miejscem spotkań, spontanicznych interakcji, wzajemnych inspiracji pracowników oraz wzmacniania ich identyfikacji z pracodawcą. Zmieni się struktura budynku na bogatszą część usługową, część co-workingową i biur elastycznych oraz tradycyjną część powierzchni biurowych na wynajem, lecz jako takie budynki biurowe będą dalej potrzebne.

Słowa kluczowe: architektura, przestrzeń biurowa, budynki biurowe, Covid-19.

\section{INTRODUCTION}

Most sectors of the economy were affected by the pandemic. Its impact is likely to be long-term and profound. This paper is dedicated to an attempt to answer the question of what changes await office space and office buildings in the future.

It can now be seen that medical recommendations for social distancing have become a modus operandi of behavior, and are adopted by users and office owners as direct recommendations for daily activities. The situation related to the pandemic has had a dynamic impact on the way of working, the revision of the need to maintain large, centralized offices by institutions and the formulation of the need to correct the operation of buildings and office spaces.

The changes to design are generated by the following factors: the desire to protect health, direct legal conditions - e.g. specifying the minimum social distance or density, the need to change the behavior of employees - e.g. the need to disinfect, sanitize, use specific spaces and protect staff against forced quarantine as a result of contact with an infected person.

It can be concluded that the first effect of the pandemic is to complete the paradigm underlying the design of buildings and office spaces. In this respect, the previous optics of pursuing employee satisfaction, motivation and productivity (Boland et al. 2020) has been supplemented with the issue of their health and well-being (Parker, 2020). Due to the limitations related to the epidemic situation, we attach greater importance to the quality of the surrounding space (Zoppi 2021), which translates into a deeper perception of the office building - as part of the urban fabric and striving to ensure greater diversity and quality of the common space of office buildings and offices.

Before the pandemic, it was known that more flexible treatment of office work brings greater effect and value of the work performed, but the inert practice of introducing changes in corporations slowed down the changes. It had to be modified as a result of the pandemic and the lockdown, which forced the dynamic introduction of new solutions (Poly 2020).

The situation related to the Covid-19 epidemic accelerated the introduction of the existing trends, but also meant that new solutions had to emerge which would have an impact on the design of office space and office buildings themselves. This text is dedicated to diagnosing the directions of these very changes.

\section{RESEARCH METHODOLOGY}

The method of work was the collection of literature, professional reports and publications, monitoring and participation in the ongoing debate, as well as research, design and analytical work carried out while working in the design office. The collected, rich source material of professional literature was examined in terms of identifying basic, leading trends and formulating conclusions relating to the subject. The results were grouped into basic type of actions relating to problem solutions. In addition, the determination of the research results was overlapped with the conclusions collected during the author's professional work related to the design of buildings with an office function, which from March 2020 dealt with the issue of protecting the environment of the designed objects from an unfavorable epidemic situation. Researching the topic both by analyzing the sources and searching for original solutions together with representatives of developers and commercialization specialists constitute the basis of this text and drawn conclusions. 


\section{TYPES OF SOLUTIONS INTRODUCED INTO THE OFFICE SPACE AS AN ANSWER TO AN EPIDEMIC THREAT}

Based on the conducted analysis and research, the following groups of solutions can be distinguished in the field of changing the operation of office buildings and the working environment in the office space, which are a response to the pandemic threat:

\section{A group of procedural solutions}

Including solutions consisting in changing the operation of offices through organizational changes of management. An example is the reduction by $90 \%$ of employers in Poland in the number of people who can stay in the premises at the same time (Bojęć and others 2021), the introduction of rotation work for some employees or the limitation of the use of common spaces by the building administration (Sochacka 2020). The change also took place in the development and expansion of the information policy in the relations between tenants of office space and administration. There was a flow of information on the concentration of users, the occurrence of infections and the presentation of contacts between infected and non-infected people in order to limit the extent of the spread of the epidemic. The introduced procedural solution, apart from the control and compliance with the sanitary regime imposed by the regulations, was also the introduction of internal rules and regulations by the managers of individual buildings and office spaces.

Actions were introduced, such as measuring the temperature, controlling meetings, guests, cleaning and disinfecting rooms more frequently (Bojęć et al. 2021). Some managers introduced centralized collection of parcels for all tenants at the reception desk and the organization of mail rooms or separate entrances and exits to buildings in order to reduce contact.

\section{A group of technical and architectural solutions}

The first type of technical solutions that can be implemented are of architectural type - first of all, those that can be carried out in a simple, non-invasive and short time manner in order to improve sanitary conditions, especially assuming a low budget. They consist of reorganization of the office space, reducing the density, introducing lightweight partitions, panels and walls and the elimination of multi-person desks, especially workplaces located opposite to each other. Individual stands for online training, acoustic videoconference rooms, open spaces for quick meetings may also be introduced. The type of equipment beneficial in a pandemic situation are mobile partitions and modular furniture, allowing for rearrangement and easy reconfiguration: which can be set up, put together or partially dismantled and rented to employees (Property News 16/02/2021). As a result of these experiences, it can be concluded that the space and equipment in the near future should not be designed with permanent solutions (Sochacka, 2020).

In terms of solutions of interior design, advantageous is to limit the use of materials that are difficult to disinfect, and the use of openable windows will become a standard (Bojać et al. 2021). At the same time, nearly $70 \%$ of companies want to pay more attention to the well-being of employees after the pandemic (Knight Frank 2020). It follows that, for example, green roofs and terraces, natural light, rich elements of biophilia - greenery in the office, spaces for quiet work and relaxation rooms will be often implemented solutions in future office buildings.

The conducted studies show that it is also possible to introduce solutions that change the traditional structure of an office building. They can be introduced in newly designed buildings and are related to the improvement of circulation and rearrangement of common spaces in order to improve social distance, or they can consist in increasing the volume of space in zones intended for places of meeting people. A typical scheme of vertical circulation in office buildings consists of one elevator lobby from which a group of elevators serving all floors is accessible (Fig. 1). This promotes the transmission of the virus because all users of the building can potentially meet in the elevator lobby space and can come into contact with each other while moving in the elevator. The solution, which as a result of variant analyzes turned out to be beneficial in terms of limiting virus transmission, was the division of elevators into groups serving separate floors and the introduction of escalators serving the first floor during the research work (Fig. 2). It allows to lower the number of possible 
contacts of users in elevators and, when the elevator lobby is separated it limits virus transmission in its space.

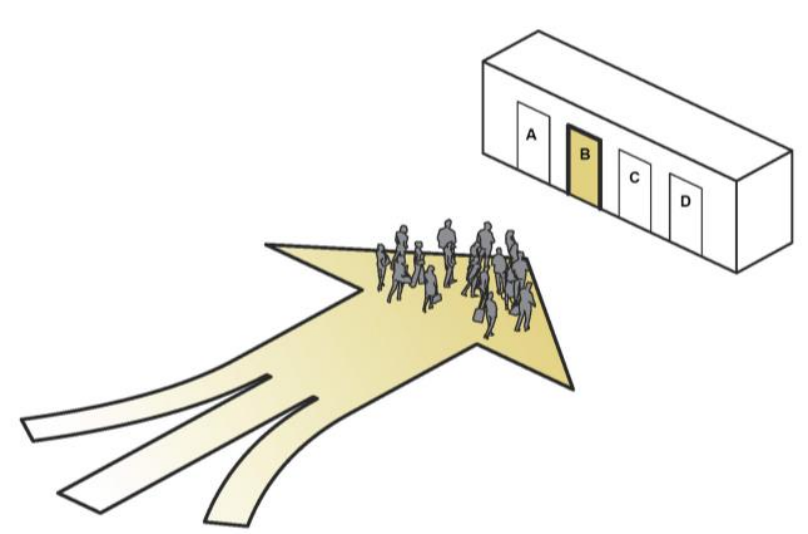

Schemat: Windy

Fig. 1. Diagram of a traditional solution for vertical communication in office buildings. Common lobby on the ground floor with one group of lifts serving all floors. Source: author's compilation, Kuryłowicz \& Associates

Ryc. 1. Schemat tradycyjnego rozwiązania komunikacji pionowej w budynkach biurowych. Wspólne lobby na parterze do jednej grupy wind obsługującej wszystkie piętra. Żródło: opracowanie autora, Kuryłowicz \& Associates

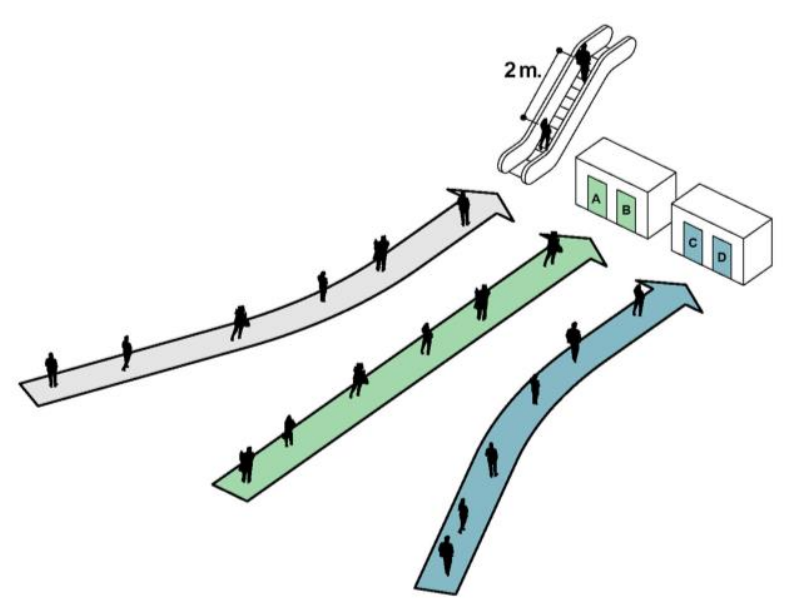

Schemat: Windy

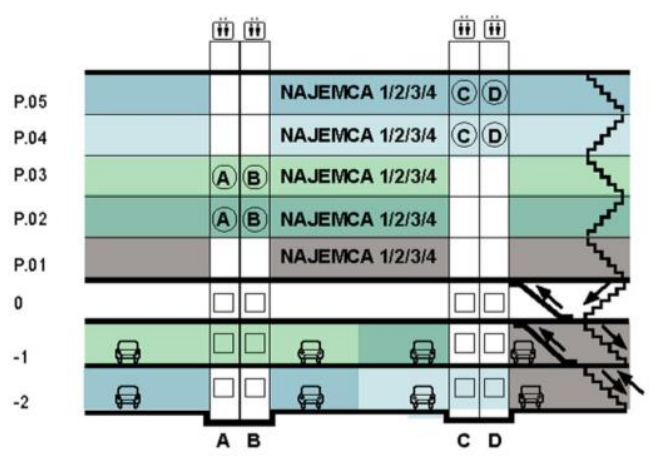

Fig. 2. Diagram of an alternative solution for vertical communication in office buildings. Separation of elevator groups to serve different floors, service of the first floor level by escalators. Source: author's compilation, Kuryłowicz \& Associates

Ryc. 2. Schemat alternatywnego rozwiązania komunikacji pionowej w budynkach biurowych. Rozdzielenie grup wind na obsługujące różne kondygnacje, obsługa poziomu pierwszego piętra przez schody ruchome. Źródło: opracowanie autora, Kuryłowicz \& Associates

In case of an underground garage, the above strategy should be combined with the separation of parking zones for servicing individual floors and for individual tenants in order to limit the possibility of accidental contacts between users of different floors in the garage portion of the building. 


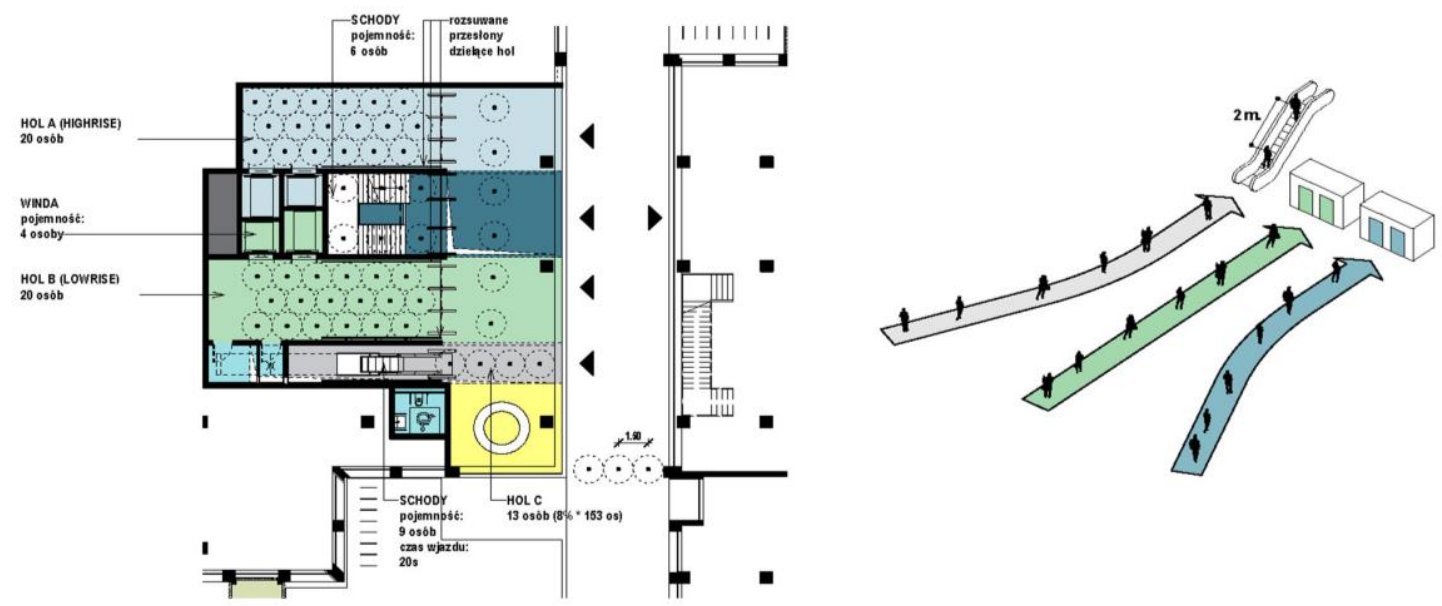

Fig. 3. Diagram of the temporary separation of the entrance hall into the lobby of elevator groups serving a separate floor and the zone of access to the escalator leading to the first floor level, with separate entrances from the outside. Source: author's compilation, Kuryłowicz \& Associates

Ryc. 3. Schemat czasowego rozdzielenia hallu wejściowego na lobby grup wind obsługujących oddzielne kondygnację i strefe dostepu do schodów ruchomych prowadzacych na poziom pierwszego piętra, z zapewnieniem oddzielnych wejść z zewnątrz. Żródło: opracowanie autora, Kuryłowicz \& Associates

A good solution is to use emergency staircases as part of the basic vertical circulation, because in this form of movement between floors it is possible to keep a required social distance, which is impossible in the case of using elevators (Fig. 4). In order to provoke a greater share of staircases in vertical circulation, it is advantageous to place them in front of the groups of elevators, not traditionally hidden behind them, and to open them with glass walls towards the elevator hall.

The conducted research on possible modifications to the lease space has shown that a positive solution from the point of view of limiting virus transmission is designating of the portion of lease space in which meeting rooms can be arranged and increasing of their cubature (Fig. 5).

This gives a greater amount of air per capita in such spaces and, together with the appropriate arrangement of the installation ensuring the right number of air changes per hour, has a positive effect on lowering the dispersion of the aerosol containing virus particles.

The analyzes also revealed that in the office space, sanitary and social rooms are places of gathering of employees, conducive to reducing the social distance. In order to reduce the risk of virus transmission in these areas, the solution developed during the analyzes was to disperse social rooms into several smaller ones and to give up common lobbies in sanitary rooms. A comparison of the traditional model system with the system taking into account these solutions is shown in Fig. 6 . Installation solutions are the second group of solutions introduced and considered for implementation. In this respect, air purity and quality are of key importance for the quality of work, employees' well-being and the reduction of epidemiological risks. This is a direct result of the role of micropollutants and humidity in the transmission of viruses and microorganisms. An example of a solution for air purification systems is e.g. the RCl Active Pure technology implemented by Echo Development, UV decontamination systems that can be introduced into the installation (Bojęć et al. 2021) or the installation of additional filters in ventilation systems, e.g. HEPA or EAC. Installation solutions include: complete abandonment of air recirculation, increased ventilation with outside air, increasing the level of air filtration to MERV-13 (90\% of particles are filtered, 3-10ppm), ensuring the operation of the installation for longer periods of time (optimally 24/7), equipping the space with portable air purifiers, if necessary, adding devices with UV decontamination (e.g. lamps), maintaining the temperature and humidity in the range appropriate to reduce transmission by a given aerosol (for Covid-19 it was assumed that the optimal humidity was the air that prevents transmission of the virus is in the range of $40 \%-60 \%$ ). 
Fig. 4. Diagram of the use of emergency staircases as an element supporting the main vertical communication in an office building. Source: author's compilation, Kuryłowicz \& Associates Ryc. 4. Schemat wykorzystania klatek ewakuacyjnych jako elementu wspomagającego główną komunikację pionową w budynku biurowym. Zródło: opracowanie autora, Kuryłowicz \& Associates

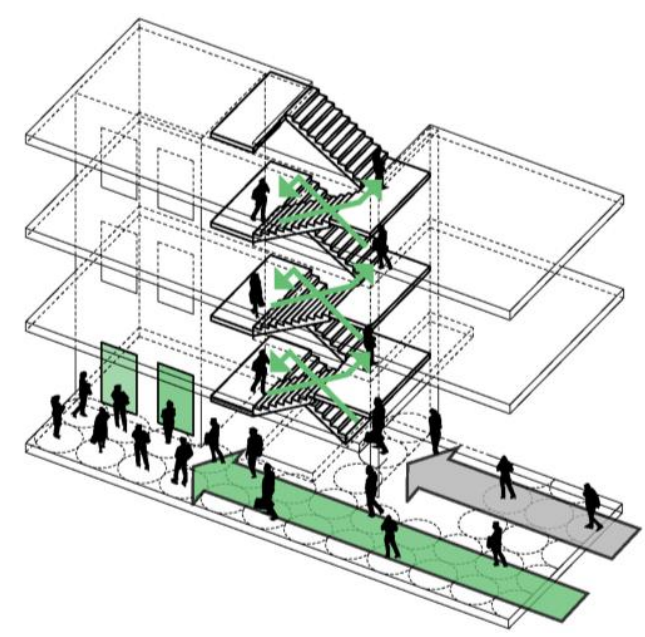

Schemat: Dwukondygnacyjne sale dla większych grup ludzi.
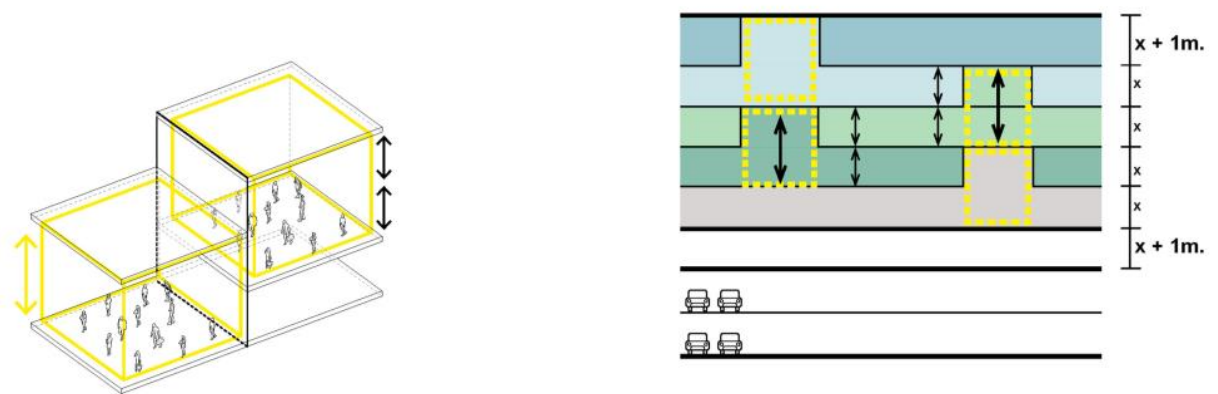

Fig. 5. Scheme of introducing space with increased cubature into the structure of an office building. Source: author's compilation, Kuryłowicz \& Associates

Ryc. 5. Schemat wprowadzanie przestrzeni o zwiększonej kubaturze w strukturę budynku biurowego. Źródło: opracowanie autora, Kuryłowicz \& Associates
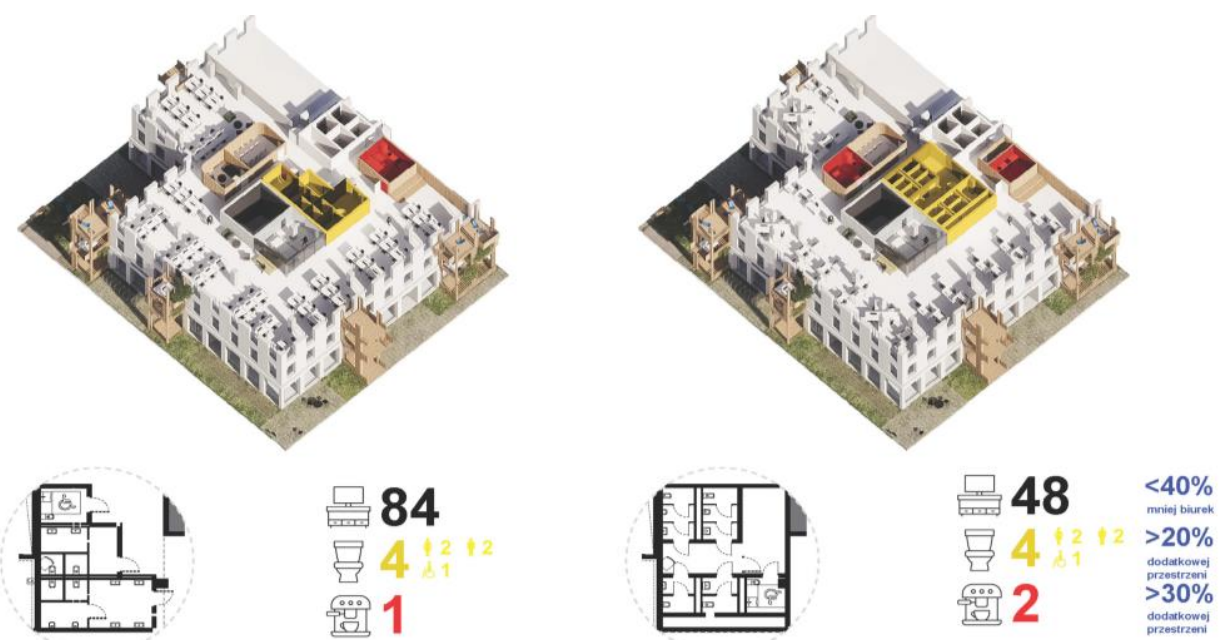

Fig. 6. Comparison of the traditional arrangement of an office floor with an arrangement adapted to the epidemic situation. Source: author's compilation, Kuryłowicz \& Associates.

Ryc. 6. Porównanie tradycyjnej aranżacji piętra biurowego z aranżacją dostosowaną do sytuacji epidemicznej. Źródło: opracowanie autora, Kuryłowicz \& Associates. 
Another type of installation are low-voltage installations. In order to minimize the transmission of the virus, modern control systems (e.g. infrared cameras for temperature screening tests, cameras for detecting masks) and advanced digital solutions are introduced. The group of control solutions is aimed at creating a contactless office, in which the need to use handles, buttons (e.g. for elevators, control systems) is eliminated, and control is possible by installing an application in the telephone or contactless cards. Digital solutions are heading towards the integration of all building systems with the installation of additional sensors (e.g. humidity sensors, CO2 concentration, dust, volatile particles, occupancy sensors) and cameras. Due to the combination of internet of things devices and building systems, it will be possible to collect information for building management and sanitary safety in a more extensive and precise manner. The system will be able to recognize and inform about disturbing events and react to them. This may include, for example air quality and quantity, temperature and humidity levels, contact tracking, transmission of density data and the location of people in building zones. The situation in the building is monitored in terms of the set parameters and visualized in the manager's application and in applications made available to users on mobile phones. It will make the use of the office safer, more functional and optimized. The system can inform, e.g. during a meeting, about exceeding the time or the number of people in the room, and after the meeting, block the room and turn on the UV disinfection systems. An example of an application showing how the office is used on mobile devices is, for example Symbiosy a digital reflection of the office - an application implemented by HB Reavis, collecting information about the location of employees via a network of sensors, which allows for monitoring and maintaining social distance, booking rooms, finding free space and people with whom a person infected with Covid-19 has come into contact. The application integrates the technical resources of the office, once installed on a smartphone which is a contactless key to the building and office. Integration takes place with all building systems - cameras, information about parking spaces, access control, compaction, operation of installation systems.

\section{Remote work}

Remote work is a solution, the introduction of which in Poland was directly prompted by the provisions of the special act of April 8, 2020 (Ustawa 2020), giving the employer the opportunity to refer an employee to remote work by order. As a result of these conditions in Poland, the percentage of people working remotely more than doubled for all labor sectors - from $4.6 \%$ before the pandemic to $13.1 \%$ in Q2 2020 (Bojęć et al. 2021, data for all sectors of the economy). A large scale of this phenomenon also took place abroad - e.g. in the United States, in June 2020, the percentage of people working remotely reached $62 \%$ of employees (Boland et al. 2020). The remote work experience turned out to be positive for both employers, who in the research in $85 \%$ stated that the flexibility of the workplace leads to greater efficiency, and $74 \%$ of CFOs declared that they intend to permanently implement remote work of employees (Poly 2020) and employees, who in the surveys stated that they were more or equally productive $-41 \%$ and $28 \%$ in the United States (Boland et al. 2020 ) and $43 \%$ and $41 \%$ in Poland (Bojęć et al. 2021), respectively. Majority of workers declares willingness to work partially remotely in the future (Poly 2020, Bojęć and others 2021). The saving of time on commuting to work is also considered a great value of remote work (Economist 2020). Despite these statistics, there are signs that a complete transition to remote work does not seem possible. In the questionnaires, factors of the lack of direct contacts, isolation and loneliness, the impression of being at work constantly and disturbance of the balance between work and home are indicated as unfavorable for remote work. As many as $37 \%$ of respondents say that in the case of this form of work, they work all day (Bojęć et al. 2021). In terms of the future amount of time dedicated to remote work, statistics show that of those working in this way during the pandemic, up to $79 \%$ declare that in the future they would like to work in this way less than 2-3 days a week (Leesman 2021) with the prospect of working in average offices, and this percentage increases to $92 \%$ for work in offices of the highest standard. This proves that remote work will not be the only form of employment in corporations that decide to introduce it in the future. It can be observed that due to the remote work during the pandemic, office tenants have largely revised their rental policy. Part of the office space was considered unnecessary for hybrid or remote work, and the situation of uncertainty meant that a large group of organizations decided to renegotiate lease agreements or run subleases. Flexible offices and coworking offices were gaining popularity, where, in along with 
free-lancers, work was often carried out by people employed by corporations (Magazif 2020). The situation of access to flexible offices and the possible resignation from it, as the situation develops, have become an attractive form of providing workplaces for many organizations (Knight Frank 2021). Many developers have decided to purchase or create their own co-working brands (eg Echo Investment - City Space, HB Reavis - HubHub, Skanska - Business Link, Adgar - Brain Embassy). It is estimated that in the coming years the amount of coworking space will increase by $40 \%$ (Global Coworking Growth Study 2020).

\section{SUMMARY}

The threat of a pandemic and the related conclusions for the design and location of office buildings change the current perspective and practice of their implementation. In result the world of office buildings is undergoing significant changes. The corporation pressure to densify office spaces has decreased, the principle of work organization has changed, consisting in placing workstations opposite each other, the $1.8 \mathrm{~m}$ desk module is has come back instead of the $1.4 \mathrm{~m}$ module introduced in the time before the pandemic. Workplaces and hot-desks, along with densifying of space, proved to be unfavorable to limiting virus transmission.

The situation in which office work was perceived as carried out in one seat of a monolithized organization is a thing of the past - post-covid work organization will consist more in a smooth transition from stationary and remote work within the network of connections that make up the work system. Within this network, the physical location of the headquarters will be of smaller importance. More important than the workplace location will be the efficiency and effectiveness of communication and the ability to convey ideas within the organization and its clients. The employer's approach to the employee must also change. They must be trusted with greater trust in hybrid work, and the work culture must change towards greater employee inclusiveness and an emphasis on teamwork.

Certainly, the future will bring greater integration of places of residence and offices - dedicated workplaces built into flats and flexible work carried out in multiple locations. There will be an increase in the share of hybrid work with the probable model of work in homes and meetings at company headquarters, and a reduction in the size of the layout of office space occupied by the organization, with possible dispersion into many locations. The use and development of remote work technology will deepen, including also mobile devices. The very word "work" will cease to be synonymous with the place of human activity in the long run - it will first of all become a synonym for activity.

It is unlikely that office buildings as such are no longer needed. This is indicated by research showing the shortcomings of remote work. Therefore, the transition to remote work to a large extent does not seem entirely possible. The solution implemented in the future will probably be hybrid work - partly carried out remotely, with a certain period of work in the office.

It follows that probably the central office of the organization may be limited in size and its role will change. Its important function in the future will be enabling employees to meet, provoke spontaneous interactions and mutual inspiration, which cannot happen during remote work situations. This will affect the arrangement of office space - there will be a decline in individual workplaces in favor of common spaces, meetings and exchange of ideas. Offices from unified plans will move towards individualization, choice, contrast and diversity of space. Their role in the future will also be to motivate and inspire employees, in addition to providing them with comfort and ergonomics unavailable in the case of remote work at homes.

A very important role of the office will be to strengthen identification with the employer. The office will become a place for creating and displaying the culture and values of the organization and should in the future become a place with which the employee will want to identify. This, in turn, will increase the pressure of employees on the implementation of the principles by the design of office space and buildings in which its users believe, especially those from the new generation entering the labor market. Most of the facilities under construction will be subject to high score certification of the LEED and BREEAM pro-environmental policy, and WELL and Fitwell - the certificates con- 
cerning the well-being of users will be more and more common. Appropriate environment, air quality and humidity, ensuring a large amount of natural light, ecological materials and biophilic design will become a standard. Existing buildings will be simultaneously modernized and certified to remain competitive in the lease market.

Future projects will have to provide for quick and easy adaptation - office buildings must be flexible and allow tenants to increase and decrease space. This will have an impact on the design of the floor plans of these buildings with anticipating the introduction of many smaller tenants on the floor and joining or dividing the lease area. This policy will make it possible to adjust the floor plan layout to a situation when, for example, a bigger tenant decides to vacate half of its space. The vacated part should allow the introduction of an independent, different tenant, and the building solutions should allow it.

The structure of the office building will also be a subject to change. In the future, it can be expected that the office building will consist of a more prestigious part offered to corporate tenants as offices for rent, perhaps in smaller office units consisting of 4 to 6 on one floor, and a large part of coworking or flexible offices offered as additional jobs for employees. The tactic of creating a "great-user experience" - offered by the building - a range of additional services for tenants that they can use will be very important as the possibility of offering services available to employees and unavailable for homework. The service part of the office building will increase its multi-functionality - in addition to gastronomy and cafes, it will be enriched with, for example, trade, gymnasiums, wellness, event spaces, training rooms and meeting places.

Changes are expected to take place slowly in the coming months, as most employees work remotely, but certainly the following years will be the period of introducing modifications to the designs of buildings and office spaces as the lesson of pandemic is being learnt. Nonetheless it can be concluded that although office spaces and buildings are expected to be modified, they will still be needed.

\section{WPŁYW ZAGROŻENIA EPIDEMICZNEGO NA PROJEKTOWANIE BIUR I BUDYNKÓW BIUROWYCH}

\section{WSTĘP}

Skutki pandemii dotknęły większość sektorów gospodarki. Jej wpływ będzie prawdopodobnie długofalowy i głęboki. Niniejsza praca poświęcona jest próbie odpowiedzi na pytanie jakie zmiany czekają w związku z nią biura i budynki biurowe w przyszłości.

Obecnie można zaobserwować, że zalecenia medyczne dotyczące społecznego dystansowania stały się modus operandi zachowań, oraz są przyjmowane przez użytkowników i właścicieli biur jako bezpośrednie zalecenia do codziennych aktywności. Sytuacja związana z pandemią w dynamiczny sposób wpłynęła na sposób pracy, rewizję potrzeby utrzymywania dużych, scentralizowanych biur przez instytucje oraz sformułowanie potrzeby korekty działania budynków i przestrzeni biurowych.

Zmiany generowane są przez następujące czynniki: chęć ochrony zdrowia, bezpośrednie uwarunkowania prawne - np. określające minimalny dystans społeczny lub zagęszczenie, potrzebę zmiany zachowań pracowników - np. konieczność dezynfekcji, korzystania z określonych przestrzeni oraz uchronienie kadry przed przymusowym pobytem na kwarantannie w wyniku kontaktu z osobą zakażaną.

Można stwierdzić że pierwszym efektem pandemii jest uzupełnienie paradygmatu leżącego u podstaw projektowania budynków i przestrzeni biurowych. Pod tym względem dotychczasowa optyka 
dążenia do satysfakcji , motywacji i produktywności pracowników (Boland i inn. 2020) została uzupełniona o kwestię ich zdrowia, dobrego samopoczucia i dobrostanu (Parker, 2020). Ograniczenia związane z sytuacją epidemiczną sprawiła że większą wagę przywiązujemy do jakości otaczającej nas przestrzeni (Zoppi 2021), co przekłada się na głębsze postrzeganie budynku biurowego - jako części tkanki miejskiej oraz dążenie do zapewnienia większej różnorodności i jakości przestrzeni wspólnej biurowców i biur.

Przed sytuacją pandemii wiedziano że bardziej elastyczne traktowanie pracy biurowej przynosi większy efekt i wartość wykonywanej pracy, jednak inercyjna praktyka wprowadzania zmian w korporacjach spowalniała zmiany. Musiało to zostać zmienione w wyniku pandemii oraz lockdownu, które wymusiły dynamicznie wprowadzanie nowych rozwiązań (Poly 2020).

Sytuacja związana z epidemią Covid-19 przyspieszyła wprowadzanie istniejących trendów, ale i sprawiła że musiały pojawić się nowe rozwiązania które odcisną się na sposobie projektowania przestrzeni pracy biurowej i samych budynków biurowych.

Zdiagnozowaniu kierunków tych zmian poświęcony jest niniejszy tekst.

\section{METODY BADAWCZE}

Metodą pracy były zebranie literatury oraz raportów i publikacji profesjonalnych, śledzenie i uczestnictwo w toczącej się debacie oraz prowadzone prace badawcze, projektowe i analityczne wykonywane podczas pracy w biurze projektowym. Zebrany, bogaty materiał źródłowy literatury fachowej został zbadany pod kątem rozpoznania podstawowych, wiodących trendów oraz sformułowania wniosków odnoszących się do przedmiotu. Wyniki zostały pogrupowane na podstawowe typu działań odnoszących się do rozwiązań problemu. Dodatkowo na określenie wyników badań nałożyły się wnioski zebrane podczas prowadzonej przez autora pracy zawodowej związanej z projektami budynków o funkcji biurowej, która od marca 2020 dotykała problematyki zabezpieczenia środowiska projektowanych obiektów od niekorzystnej sytuacji epidemiologicznej. Badanie tematu zarówno przez analizę źródeł jak i szukanie autorskich rozwiązań projektowych wspólnie z przedstawicielami deweloperów i specjalistów komercjalizacji stanowią podstawę niniejszego teksu i wyciągniętych wniosków.

\section{TYPY ROZWIAZAŃ WPROWADZANYCH DO PRZESTRZENI BIUROWEJ JAKO ODPOWIEDŹ NA ZAGROŻENIE EPIDEMICZNE}

Na podstawie przeprowadzonej analizy i prac badawczych można wydzielić następujące grupy rozwiązań w zakresie zmiany działania budynków biur i środowiska pracy w przestrzeni biurowej stanowiących odpowiedź na zagrożenie pandemiczne.

\section{Grupa rozwiązań proceduralnych}

Obejmująca rozwiązania polegające na zmianie działania biur poprzez zmiany organizacyjne w zakresie zarządzania. Przykładem jest ograniczenie przez 90\% pracodawców w Polsce ilości osób mogących przebywać jednocześnie w pomieszczeniach (Bojęć i inni 2021), wprowadzanie pracy rotacyjnej dla części pracowników czy też ograniczenie użytkowania części wspólnych przez administrację budynku (Sochacka, 2020). Zmiana nastąpiła także w rozwoju i rozszerzeniu prowadzonej polityki informacyjnej w relacjach pomiędzy najemcami powierzchni biurowej a najmującymi. Nastąpił przepływ informacji o zagęszczeniu użytkowników, występujących przypadkach zakażeń oraz przedstawiania kontaktów pomiędzy osobami zakażonymi a pozostałymi w celu ograniczenia zasięgu rozprzestrzeniania się epidemii.

Wprowadzonym rozwiązaniem proceduralnym obok kontroli i przestrzegania narzuconego przez przepisy reżimu sanitarnego było także wprowadzanie zasad i regulacji wewnętrznych przez zarządzających poszczególnymi budynkami oraz przestrzeniami biurowymi.

Wprowadzono działania polegające np. na mierzeniu temperatury, kontroli spotkań, gości, częstszym sprzątaniu i dezynfekcji pomieszczeń (Bojęć i inni 2021). Niektórzy zarządzający wprowadza- 
li centralne odbieranie przesyłek dla wszystkich najemców na recepcji i organizację mail roomów lub wydzielanie oddzielnych wejść i wyjść do budynków w celu ograniczenia kontaktów.

\section{Grupa rozwiązań technicznych, w tym architektonicznych}

Pierwszym rodzajem rozwiązań technicznych mogących zostać implementowanymi są działania architektoniczne - w pierwszej kolejności takie, które można wykonać w prosty sposób, bezinwazyjnie oraz w krótkim czasie w celu poprawy warunków sanitarnych, szczególnie przy założeniu niskiego budżetu. Polegają na reorganizacji przestrzeni biurowej, zmniejszeniu zagęszczenia, wprowadzeniu lekkich przegród, paneli i ścianek i eliminację wieloosobowych biurek, zwłaszcza miejsc pracy lokalizowanych naprzeciwko siebie. Wprowadzane mogą zostać indywidualne stanowiska do szkoleń online, wydzielone akustycznie pokoje do wideokonferencji, otwarte przestrzenie do szybkich spotkań. Typem wyposażenia korzystnego w sytuacji pandemii są mobilne przegrody $\mathrm{i}$ meble modułowe, pozwalające na rearanżację i łatwą zmianą konfiguracji: które można rozstawić, zestawić czy częściowo zdemontować i wypożyczyć pracownikom (Property News 16.02.2021).

W efekcie tych doświadczeń można stwierdzić że przestrzeń i wyposażenie w najbliższej przyszłości nie powinny być zaprojektowane z myślą o stałych rozwiązaniach (Sochacka, 2020).

W zakresie rozwiązań wnętrz korzystnym rozwiązaniem jest ograniczenie stosowania materiałów trudnych w dezynfekcji a stosowanie otwieranych okien stanie się standardem (Bojęć i inni 2021). Jednocześnie blisko $70 \%$ firm chce po pandemii poświęcić więcej uwagi dobremu samopoczuciu pracowników ( Knight Frank 2020). Wynika z tego że na przykład zielone dachy i tarasy, naturalne światło, bogate elementy biofilii - zieleń w biurze, przestrzenie do cichej pracy i sale relaksu będą często wdrażanymi rozwiązaniami w przyszłych budynkach biurowych.

Przeprowadzone prace studialne wykazują że możliwe są także do wprowadzenia rozwiązania zmieniające tradycyjną strukturę budynku biurowego. Mogą one zostać wprowadzone w nowoprojektowanych budynkach i są związane z poprawą komunikacji i rearanżacją przestrzeni wspólnych w celu poprawy dystansu społecznego lub mogą polegać na zwiększeniu kubatury przestrzeni w strefach przeznaczonych na miejsca spotkań ludzi.

Tradycyjny schemat komunikacji pionowej w budynkach biurowych polega na jednym lobby windowym z którego dostępna jest grupa wind obsługująca wszystkie piętra (Ryc.1). Sprzyja to transmisji wirusa ponieważ wszyscy użytkownicy budynku mogą potencjalnie spotkać się w przestrzeni lobby windowego oraz mogą mieć kontakt ze sobą podczas jazdy windą. Rozwiązaniem, które w wyniku wariantowych analiz okazało się korzystne pod kątem ograniczenia transmisji wirusa stało się podczas prac badawczych rozdzielenie wind na grupy obsługujące oddzielne kondygnacje, oraz wprowadzenie schodów ruchomych obsługujących piętro pierwsze (Ryc 2). Pozwala to na ograniczenie możliwych kontaktów użytkowników w windach oraz, przy rozdzieleniu lobby windowego ogranicza transmisje wirusa $w$ jego przestrzeni.

Powyższa strategia powinna być w przypadku garażu podziemnego połączona z rozdzieleniem stref parkingowych na obsługujące poszczególne piętra i oraz poszczególnych najemców, aby ograniczyć możliwość przypadkowych kontaktów użytkowników różnych pięter w części garażowej.

Dobrym rozwiązaniem jest wykorzystanie klatek ewakuacyjnych jako części podstawowej komunikacji pionowej ponieważ w wypadku takiej formy przemieszczania się pomiędzy kondygnacjami możliwe jest zachowanie dystansu, co jest nieosiągalne w przypadku korzystania z wind (Ryc. 4). Aby sprowokować większy udział klatek schodowych w komunikacji pionowej korzystne jest umieszczanie ich przed grupami wind, a nie tradycyjnie ukrytych za nimi i otwarcie ich przeszklonymi ścianami w stronę hallu windowego.

Prowadzone badania nad możliwymi modyfikacjami przestrzeni najmu wykazały że pozytywnym rozwiązaniem z punktu widzenia ograniczenia transmisji wirusa jest wydzielenie podczas prac projektowych strefy przestrzeni najmu w której mogą być aranżowane sale spotkań oraz zwiększenie w nich kubatury (Ryc 5). 
Daje to większą ilość powietrza na osobę w takiej przestrzeni i wraz z odpowiednim rozwiązaniem instalacji zapewniającym właściwą ilość wymian powietrza na godzinę wpływa dodatnio na rozpraszanie aerozolu zawierającego cząstki wirusa.

Analizy wykazały także że $w$ ramach przestrzeni biurowej miejscami gromadzenia się pracowników, sprzyjającymi zmniejszaniu dystansu społecznego są pomieszczenia sanitarne oraz socjalne. W celu zmniejszenia ryzyka transmisji wirusa $w$ tych obszarach wypracowanym $w$ trakcie analiz rozwiązaniem może być rozproszenie pomieszczeń socjalnych na szereg mniejszych, oraz rezygnacja ze stosowania wspólnych przedsionków w pomieszczeniach sanitarnych. Porównanie modelowej aranżacji tradycyjnej z aranżacją uwzględniającą te rozwiązania pokazano na Ryc. 6.

Drugą grupą wprowadzanych i rozpatrywanych do wdrożenia rozwiązań to rozwiązania instalacyjne. W tym zakresie kluczowa dla jakości pracy, samopoczucia pracowników i zmniejszenia zagrożenia epidemiologicznego jest czystość i jakość powietrza. Wynika to bezpośrednio z roli jaką mikrozanieczyszczenia i wilgotność pełnią w transmisji wirusów i drobnoustrojów. Przykładem rozwiązania systemów oczyszczania powietrza jest np. implementowana przez Echo technologia $\mathrm{RCl}$ Active Pure, możliwe do wprowadzenia do instalacji systemy odkażania UV (Bojęć i inni 2021) lub montowanie dodatkowych filtrów w systemach wentylacji , np. filtrów HEPA lub EAC. Rozwiązania instalacyjne obejmują: całkowitą rezygnację z recyrkulacji powietrza, zwiększenie wentylacji powietrzem zewnętrznym, podniesienie poziomu filtracji powietrza do MERV-13 (filtrowane jest 90\% cząstek 3-10ppm), zapewnienie pracy instalacji w dłuższych okresach czasu (optymalnie 24/7), doposażenie przestrzeni w przenośne oczyszczacze powietrza o ile to konieczne, dodanie urządzeń z odkażaniem UV (np. lamp), utrzymywanie temperatury i wilgotności w zakresie odpowiednim dla zredukowania transmisji przez dany aerozol (dla Covid-19 przyjęto że optymalna wilgotność powietrza zapobiegająca transmisji wirusa mieści się w przedziale 40\%-60\%).

Kolejnym rodzajem instalacji są instalacje niskoprądowe. Aby minimalizować transmisję wirusa wprowadzane są nowoczesne systemy kontroli (np. kamery na podczerwień służące do przesiewowych badań temperatury, kamery do wykrywania maseczek) i zaawansowane rozwiązania cyfrowe. Grupa rozwiązań kontroli zmierza w kierunku stworzenia bezdotykowego biura, w którym wyeliminowana zostaje potrzeba korzystania z klamek, przycisków (np. do wind, systemów sterowania), a kontrolę umożliwia instalowana aplikacja w telefonie lub karty bezdotykowe. Rozwiązania cyfrowe zmierzają w kierunku integracji wszystkich systemów budynku wraz z instalacją dodatkowych czujników (np. czujników wilgotności, stężenia CO2, pyłów, lotnych cząstek, czujników zajętości) oraz kamer. Dzięki połączeniu urządzeń w internecie rzeczy (internet of things) oraz systemów budynków możliwe będzie rozleglejsze i bardziej precyzyjne zbieranie informacji służących zarządzaniu budynkiem i stanem bezpieczeństwa sanitarnego. System będzie mógł rozpoznawać i informować o niepokojących zdarzeniach oraz reagować na nie. Może to dotyczyć na przykład jakości i ilości powietrza, poziomu temperatury i wilgotności , śledzenia kontaktu, przesyłania danych o zagęszczeniu i lokalizacji ludzi w strefach budynku. Sytuacja w budynku zostaje monitorowana pod kątem zadanych parametrów oraz wizualizowana w aplikacji zarządcy oraz aplikacjach udostępnianych użytkownikom w telefonach komórkowych. Sprawi to że użytkowanie biura staje się bezpieczniejsze, bardziej funkcjonalne i zoptymalizowane. System może poinformować np. podczas spotkania o przekroczeniu czasu lub ilości osób w sali, a po spotkaniu zablokować salę i włączyć systemy dezynfekcji UV.

Przykładem aplikacji pokazującej na urządzeniach mobilnych sposób użytkowania biura jest np. cyfrowe odbicie biura Symbiosy - aplikacja zaimplementowana przez HB Reavis, zbierająca przez sieć czujników informacje o lokalizacji pracowników co pozwala na monitorowanie i zachowanie dystansu społecznego, rezerwację sal, znajdowanie wolnego miejsca i identyfikację osób z którymi miała kontakt osoba zakażona Covid-19. Aplikacja integruje zasoby techniczne biura, po zainstalowaniu w smartfonie stanowi bezdotykowy klucz do budynku i biura. Ingerowanie w całość wszystkich systemów budynku - kamery, informacje o miejscach parkingowych, kontroli dostępu, zagęszczenia, działania systemów instalacji. 


\section{Praca zdalna}

Praca zdalna jest rozwiązaniem którego wprowadzenie w Polsce bezpośrednio sprowokowały zapisy specustawy z dnia 8.04.2020 (Ustawa 2020), dającej pracodawcy możliwość skierowania pracownika do pracy zdalnej poleceniem. Wskutek tego w warunkach Polskich odsetek osób pracujących zdalnie zwiększył się ponad dwukrotnie dla wszystkich sektorów pracy- z 4,6\% przed pandemią do 13,1\% w II kwartale 2020 roku (Bojęć i inni 2021, dane dla wszystkich sektorów gospodarki). Duża skala tego zjawiska nastąpiła także za granicą - np. w Stanach Zjednoczonych w czerwcu 2020 roku odsetek osób pracujących zdalnie sięgnął 62\% pracowników (Boland i inn. 2020). Doświadczenia pracy zdalnej okazały się pozytywne zarówno dla pracodawców, którzy w badaniach w $85 \%$ twierdzili że elastyczność miejsca pracy prowadzi do większej wydajności a 74\% dyrektorów finansowych deklarowało że zamierza na stałe wdrożyć pracę zdalną pracowników (Poly 2020), jak i pracowników, którzy w ankietach twierdzili że są bardziej, lub tak samo produktywni - odpowiednio 41\% i $28 \%$ w Stanach Zjednoczonych (Boland i inn. 2020) i 43\% i 41\% w Polsce (Bojęć i inni 2021).W większości pracownicy chcieli by w przyszłości także pracować częściowo zdalnie (Poly 2020, Bojęć i inni 2021). Za duży walor pracy zdalnej uznawana jest oszczędność czasu na dojazdach do pracy (Economist 2020).

Mimo tych statystyk widoczne są oznaki wskazujące że całkowite przejście na pracę zdalną nie wydaje się możliwe. W ankietach, za niekorzystne dla pracy zdalnej wskazywane są czynniki braku bezpośrednich kontaktów, izolacji i samotności, wrażenia ciągłego bycia w pracy i zaburzenia równowagi pomiędzy pracą a domem. Aż 37\% ankietowanych stwierdza że w przypadku tej formy pracy pracują przez cały dzień (Bojęć i inni 2021). Pod katem przyszłej ilości czasu dedykowanego pracy zdalnej statystyki wskazują że z osób pracujących w ten sposób w czasie pandemii maksymalnie 79\% deklaruje że w przyszłości chciałoby pracować w ten sposób więcej mniej niż 2-3 dni w tygodniu (Leesman 2021) przy perspektywie pracy w przeciętnych biurach, zaś odsetek ten rośnie do $92 \%$ dla pracy w biurach o najwyższym standardzie. Wśród osób pracujących zdalnie $34,7 \%$ badanych stwierdziło że przeszkodą jest brak bezpośredniego kontaktu z człowiekiem, a 30,2\% wskazało brak poczucia relacji z organizacją (Bojęć i inni 2021). Świadczy to o tym że praca zdalna nie będzie w przyszłości jedyną formą zatrudnienia w korporacjach decydujących się na jej wprowadzenie. Można zaobserwować że w trakcie trwania pandemii najemcy biur w dużej mierze rewidowali swoją politykę najmu ze względu na ograniczenie pracy w siedzibach firm. Część przestrzeni biurowej została uznana za niepotrzebną w sytuacji pracy zdalnej, a warunki niepewności sprawiały że spora grupa organizacji decydowała się na renegocjacje umów najmu, lub prowadzeni podnajmu. Na popularności zyskiwały biura elastyczne, coworkingu, gdzie oprócz free-lancerów pracę prowadziły często osoby zatrudniane w korporacjach (Magazif 2020). Sytuacja dostępu do biur elastycznych i ewentualna, w miarę rozwoju sytuacji rezygnacja z niego stały się dla wielu organizacji atrakcyjną formą zapewnienia miejsc pracy (Knight Frank 2021). Wielu deweloperów zdecydowało się na zakup lub tworzenie własnych marek co-workingu (np. Echo Investment - City Space, HB Reavis - HubHub, Skanska - Business Link, Adgar - Brain Embassy). Szacuje się, że w najbliższych latach ilość przestrzeni coworkingowej wzrośnie o 40\% (Global Coworking Growth Study 2020).

\section{PODSUMOWANIE}

Sytuacja zagrożenia pandemią i wiążące się z nią wnioski do projektowania i lokalizacji budynków biurowych zmieniają dotychczasową perspektywę i praktykę ich realizacji. Świat budynków biurowych przechodzi w wyniku pandemii znaczne zmiany. Zmniejszyła się presja korporacji na dogęszczanie przestrzeni biurowych, zmieniła zasada organizacji pracy polegająca na lokowaniu stanowisk pracy naprzeciw siebie, następuje powrót do modułu biurka 1,8 m zamiast wprowadzonego w czasie przed pandemicznym modułu $1,4 \mathrm{~m}$. W sytuacji pandemicznej zmienne miejsca pracy i hotdeski wraz z przegęszczeniem przestrzeni okazały się nie sprzyjające ograniczaniu przenoszenia wirusa.

Sytuacja w której praca biurowa była postrzegana jako prowadzona w jednej siedzibie zmonolityzowanej organizacji została zakwestionowana - post-covidowa organizacja pracy polegać będzie 
bardziej na płynnym przechodzeniu z pracy stacjonarnej i zdalnej w ramach sieci powiązań tworzących system pracy. W ramach tej sieci fizyczna lokalizacja siedziby będzie miała mniejsze znaczenie.

Bardziej niż miejsce pracy ważna będzie bardziej sprawność i efektywność komunikacji oraz zdolność do przekazywania pomysłów i idei wewnątrz organizacji i jej klientom.

Zmienić się musi także podejście pracodawcy w stosunku do pracownika. Musi on zostać obdarzony większym zaufaniem w pracy hybrydowej, a kultura pracy musi zmienić się w kierunku większej inkluzywności pracownika i nacisku na pracę zespołową.

Obserwacja trendów wskazuje że najprawdopodobniej przyszłość przyniesie większą integrację miejsc zamieszkania i biur - dedykowanych miejsc pracy wbudowanych w mieszkaniach i elastyczną pracę prowadzoną w wielu lokacjach. Nastąpi wzrost udziału pracy hybrydowej przy prawdopodobnym modelu pracy w domach i spotkań w siedzibach firm oraz zmniejszenie zajmowanego przez organizację rzutu przestrzeni biurowej przy możliwym jej rozproszeniu na wiele lokacji. Pogłębi się użycie i rozwinie technologia pracy zdalnej, obejmująca też urządzenia mobilne. Samo słowo praca przestanie w dłuższym czasie być synonimem miejsca działań ludzi - stanie się przede wszystkim synonimem aktywności.

Nie wydaje się prawdopodobne, żeby budynki biurowe jako takie przestały być potrzebne. Wskazują na to badania pokazujące niedostatki pracy zdalnej. Dlatego przejście do pracy zdalnej w dużym wymiarze nie wydaje się w przyszłości całkowicie możliwe. Rozwiązaniem wdrażanym w przyszłości będzie prawdopodobnie praca hybrydowa - częściowo prowadzona zdalnie, z pewnym okresem prowadzonej pracy w biurze.

Wynika z tego że biuro centralne organizacji może zostać powierzchniowo ograniczone, a jego rola się zmieni.

Jego ważną funkcją będzie w przyszłości umożliwianie pracownikom spotkań, spontanicznych interakcji sprzyjających bezpośredniej, wzajemnej inspiracji które nie mogą zdarzyć się podczas sytuacji zdalnej pracy. Wpłynie to na sposób aranżacji przestrzeni biurowej - nastąpi w jej ramach spadek miejsc indywidualnej pracy na rzecz przestrzeni wspólnych, spotkań i wymiany pomysłów. Biura ze zuniformizowanych planów przejdą w kierunku indywidualizacji, wyboru, kontrastu i różnorodności przestrzeni, której rolą będzie także motywowanie i inspirowanie pracowników, oprócz zapewnienia im komfortu i ergonomii niedostępnej w wypadku pracy zdalnej.

Bardzo ważną rolą biura stanie się wzmacnianie identyfikacji z pracodawcą. Biuro stanie się miejscem tworzenia i eksponowania kultury oraz wartości organizacji i powinno w przyszłości stać się miejscem z którym pracownik będzie chciał się utożsamiać. To z kolei wpłynie na zwiększenie presji pracowników na realizację przez projekty przestrzeni i budynków biurowych zasad w które wierzą użytkownicy, zwłaszcza ci, spośród wkraczającego na rynek pracy nowego pokolenia pracowników. Większość realizowanych obiektów będzie poddawana wysokiej certyfikacji dotyczącej realizacji polityki pro-środowiskowej LEED i BREEAM, wkroczą coraz powszechniej certyfikacje dotyczące dobrostanu użytkowników - WELL i Fitwell. Pod względem poprawienia dobrostanu pracowników standardem staną się odpowiednie środowisko, jakość i wilgotność powietrza, zapewnienie dużej ilości naturalnego świtała, ekologiczne materiały oraz biophilic design. Istniejące budynki będą jednocześnie poddawane modernizacjom i certyfikacji aby utrzymać konkurencyjność na rynku najmu.

Przyszłe projektu będą musiały przewidywać szybką i łatwą adaptację - biurowce będą musiały stać się bardziej elastyczne i umożliwiać zwiększanie i zmniejszanie powierzchni przez najmujących. Wpłynie to na projektowanie rzutów pięter tych budynków pod kątem przewidzenia wprowadzania wielu mniejszych najemców na piętrze oraz łączenia lub dzielenia powierzchni najmu. Umożliwi to dostosowanie układu rzutu piętra do sytuacji gdy na przykład najemca decyduje się na zwolnienie połowy swojej powierzchni. Zwalniana połowa powinna umoźliwiać wprowadzenie niezależnego, innego najemcy a rozwiązania budynku powinny to umożliwiać.

Zmiana czeka także strukturę budynku biurowego. W najbliższych latach ilość przestrzeni coworkingowej wzrośnie zaś w dalszej przyszłości można się więc spodziewać że budynek biurowy bę- 
dzie składał się z bardziej prestiżowej części oferowanej najemcom korporacyjnym jako biura na wynajem, być może w mniejszych niż dotychczas powierzchniach jednostek biurowych, składających się po kilka na jedno piętro, oraz dużej części coworkingu lub biur elastycznych oferowanych jako dodatkowe miejsca pracy dla pracowników. Bardzo ważne w sytuacji możliwości oferowania usług dostępnych dla pracowników a niedostępnych w przypadku pracy domowej będzie taktyka tworzenia "great-user experience" - oferowana przez budynek - paleta dodatkowych usług dla najemców z której mogą korzystać. Cześć usługowa budynku biurowego zwiększy swoją wielofunkcyjność - oprócz gastronomii, kawiarni, będzie wzbogacana o np. handel, gimnazjony, wellness, przestrzenie eventowe, sale szkoleń i miejsca spotkań.

Należy się spodziewamy że w najbliższych miesiącach zmiany będą zachodziły powoli, gdyż większość pracowników pracuje zdalnie. Dopiero kolejne lata będą okresem wprowadzania modyfikacji do projektów budynków i przestrzeni biurowych, które, jakkolwiek w innej formie i po zmianach w dalszym ciągu będą potrzebne.

\section{BIBLIOGRAPHY}

Bojęć T., Chimczak-Bratkowski P., Różewicz D., Tomczyk M (2021), Biura nowej normalności. Popandemiczna charakterystyka miejsc pracy, Thinkco.pl, https://thinkco.pl/biura-nowej-normalnosci-raport/, Dostęp: marzec 2021

Boland B., De Smet A., Palter R. Sanghvi (2020), Reimagining the office and work life after COVID-19, McKinsey\&Company , 8 czerwca 2020, https:/www.mckinsey.com/business-functions/organization/ourinsights/reimagining-the-office-and-work-life-after-covid-19\#, Dostęp: luty 2021

Economist (2020) The future of the office, Covid-19 has forced a radical shift in working Habits. Mostly for the better, Economist Wrzesień 2020

Global Coworking Growth Study 2020 https://www.coworkingresources.org/blog/key-figures-coworking-growth Dostęp: luty 2021

Knight Frank (2021). Kierunki zmian $w$ budynkach biurowych, Knight Frank, https://raporty.knightfrank.com.pl/kierunki_zmian_w_budynkach_biurowych_2020, Dostęp: styczeń 2021

Leesman, "Measure Remote Working", https://bit.ly/35Sgcfp Dostęp: luty 2021

Magazif (2020), Elastyczna przestrzeń - zdrowe środowisko pracy, Magazif.com, 19 października 2020 , https://magazif.com/aktualnosci/trzy-lata-dzialalnosci-mindspace-koszyki/, Dostęp: luty 2021

Parker L.D. (2020), "The COVID-19 office in transition: cost, efficiency and the social responsibility business case ", Emerald Insight, 2020

Poly (2020), Hybrid Working Creating The "Next Normal" In Work Practices, Spaces And Culture, Poly.com, czerwiec 2020, https://connect.poly.com/rs/200-EAE-291/images/Hybrid-Working-Creating-the-NextNormal-in-Work-Practices-Spaces-and-Culture--EN.pdf, (dostęp: luty 2021)

Property News, Biura post-covid: elastyczna ewolucja zamiast rewolucji, Propertynews.pl, 16 lutego 2021, https://www.propertynews.pl/biura/biura-post-covid-elastyczna-ewolucja-zamiast-rewolucji,89073.html, Dostęp: luty 2021

PropertyNews.pl (22.02.2021), Nadchodzi nowa era w projektowaniu biur, propertynews.pl, 22 lutego 2021, https://www.propertynews.pl/biura/nadchodzi-nowa-era-w-projektowaniu-biur,89488.html, Dostęp: marzec 2021

Sochacka M. (2020), Elastyczna przestrzeń - zdrowe środowisko pracy, Magazif.com, 22 maja 2020, https://magazif.com/wnetrza-publiczne/biura/elastyczna-przestrzen-zdrowe-srodowisko-pracy/, Dostęp: luty 2021

Ustawa z dnia 2 marca 2020 r.o szczególnych rozwiązaniach związanych z zapobieganiem, przeciwdziałaniem i zwalczaniem COVID-19,innych chorób zakaźnych oraz wywołanych nimi sytuacji kryzysowych. (2020), Dziennik Ustaw Rzeczypospolitej Polskiej, poz 374, 7 marca 2020

Zoppi D. (2021), Architektura w epoce postcovidowej, Zawód Architekt 77 


\section{AUTHOR'S NOTE}

Adjunct at Warsaw Univeristy of Technology. Working in Warsaw. Author of publications: book chapters, scientific articles. In research and teaching he focuses on the relationship between the architecture of industrial facilities and the architecture of public buildings. Adjunct at Faculty of Architecture, Warsaw University of Technology. Head of Laboratory of Large Scale and Industrial Architecture,. Practicing architect, author and co-author of many projects of residential and public buildings, winner of awards and distinctions. Member of the Mazovian Chamber of Architects, the Association of Polish Architects, the Association of Polish Town Planners. SARP competition judge, construction expert in the field of planning, design, coordination and supervision over the implementation of the investment process.

\section{O AUTORZE}

Pracujący w Warszawie. Autor publikacji: rozdziałów w książkach, artykułów naukowych. W działalności badawczej i dydaktycznej - koncentruje się na relacjach pomiędzy architekturą obiektów przemysłowych oraz architekturą budynków użyteczności publicznej. Adiunkt na wydziale Architektury PW, kierownik Pracowni Architektury Przemysłowej i Wielkoprzestrzennej w Zakładzie Projektowania i Teorii Architektury. Praktykujący architekt, autor i współautor wielu projektów budynków mieszkaniowych i użyteczności publicznej, laureat nagród i wyróżnień. Członek Mazowieckiej Izby Architektów, Stowarzyszenia Architektów Polskich, Towarzystwa Urbanistów Polskich. Sędzia konkursowy SARP, rzeczoznawca budowlany w zakresie planowania, projektowania, koordynacji i nadzoru nad realizacją procesu inwestycyjnego.

Contact | Kontakt: marcin.goncikowski@pw.edu.pl 